\title{
Induction of Cytotoxic T Lymphocytes in Mice against the Principal Neutralizing Domain of HIV-1 by Immunization with an Engineered T-Cytotoxic-T-Helper Synthetic Peptide Construct
}

\author{
Juan-José LaSarte, ${ }^{*}$ Pablo Sarobe, ${ }^{*}$ Arturo Gullón, $\dagger$ \\ Jesús PRIETO, ${ }^{*}$ AND FRANCISCO BorRÁs-CUESTA*,1 \\ *Departamento de Medicina Interna y †Departamento de Genética, Universidad de Navarra, \\ Facultad de Medicina, Apartado 273, 31080 Pamplona, Spain
}

Received October 28, 1991; accepted December 30, 1991

\begin{abstract}
Peptide constructs were engineered by colinear synthesis of two short synthetic peptide determinants: a determinant recognized by $T$ helper cells $\left(T_{h}\right)$ and a determinant recognized by $T$ cytotoxic cells $\left(\mathrm{TD}_{\mathrm{c}}\right)$. Three types of constructs were synthesized: $\mathrm{TD}_{\mathrm{c}}-\mathrm{TD}_{\mathrm{h}}, \mathrm{TD}_{\mathrm{h}}-\mathrm{TD}_{\mathrm{c}}$, and $\mathrm{TD}_{\mathrm{h}}-$ $\mathrm{KK}-\mathrm{TD}_{\mathrm{c}}$, where $\mathrm{KK}$ are two lysine residues. In vivo immunization with free construct induced cytolytic lymphocytes (CTL) only in the case of $T D_{c}-T_{h}$. However, immunization with spleen cells to which these constructs had been internalized by hypertonic shock, induced CTL activity in all three cases. No CTL could be induced after immunization with free $\mathrm{TD}_{\mathrm{c}}$ in either protocol. These results indicate that cell internalization of the construct might be essential for CTL induction, and also, that "help" from the $\mathrm{TD}_{\mathrm{h}}$ seems to be required. (c) 1992 Academic Press, Inc.
\end{abstract}

\section{INTRODUCTION}

It is well established that two main types of immune responses are elicited after challenge with complex antigens; (i) the humoral, which leads to antibody production; and (ii) the cellular, which leads to the induction and proliferation of cytotoxic $T$ lymphocytes (CTL).

Our understanding of how T-cell help is provided to antibody producing B-cells has greatly benefited from immunization studies using peptide haptens linked to a peptide determinant sequence $\left(\mathrm{TD}_{\mathrm{h}}\right)^{2}$ recognized by $\mathrm{T}$-cells $(1-6)$ as well as by immunization with mixtures of hapten and $\mathrm{TD}_{\mathrm{h}}$ molecules injected in the same immunization site (7).

The cellular immune response has been studied using recombinant viral protein preparations (8-10) as well as peptides (11-17). Three different types of peptide preparations have been reported as being able to induce CTL in vivo. Carbone and Bevan (11) and Ishioka et al. (12) used trypsin-digested chicken ovalbumin fragments in C57BL/6 mice. Deres et al. (13) immunized BALB/c mice with a synthetic lipopeptide construct consisting of tripalmitoil-S-glycerylcysteinyl-seryl-serine bound to a viral

\footnotetext{
${ }^{1}$ To whom correspondence should be addressed.

${ }^{2}$ Abbreviations used: $T_{\mathrm{h}}$, determinant recognized by helper $\mathrm{T}$ cells; $\mathrm{TD}_{\mathrm{c}}$, determinant recognized by cytotoxic $\mathrm{T}$ cells.
} 
cytolytic $\mathrm{T}$-cell determinant peptide $\left(\mathrm{TD}_{\mathrm{c}}\right)$. More recently, Schild et al. (14) found that the lipophilic moiety of lipopeptide construct of Deres et al. (13) was essential for an efficient in vivo priming of CTL. Aichele et al. (15) induced CTL in BALB/c mice after priming with a free 15 -mer synthetic peptide encompassing a sequence of lymphocytic choriomeningitis virus nucleoprotein and Schulz et al. (16) found that this peptide was protective. Kast et al. (17) were able to induce protective CTL against Sendai virus after immunization of mice with a free 16-mer peptide from the nucleoprotein of the virus.

Based on the observations that the tripalmitoil-S-glycerylcysteinyl-seryl-serine moiety used in the construct of Deres et al. (13) behaves as a $\mathrm{TD}_{\mathrm{h}}$ in another type of construct (18) and the ovalbumin tryptic fragment $229-276$, which contains a predicted $\mathrm{TD}_{\mathrm{h}}$ according to Sette's algorithm (19) and a proven $T_{\mathrm{c}}(20)$, but not the 242-276 (which only contains the $\mathrm{TD}_{\mathrm{c}}$ ) is able to induce CTL in vivo (11), we speculated that synthetic colinear peptide constructs of the type $\mathrm{TD}_{\mathrm{h}}-\mathrm{TD}_{\mathrm{c}}$ or $\mathrm{TD}_{\mathrm{c}}-\mathrm{TD}_{\mathrm{h}}$ might be able to induce CTL in vivo. Ishioka et al. (12) have suggested a similar proposition; however, to our knowledge, no experimental evidence has yet been published to validate these hypothesis.

We show below that CTL induction in vivo depends on the type of peptide construct used.

\section{MATERIALS AND METHODS}

\section{Peptide Synthesis}

Peptides were synthesized by the solid phase method of Merrifield (21) using the Fmoc alternative (22). The synthesis was done manually and the ninhydrin test of Kaiser (23) was used to monitor every step. Couplings were repeated if necessary until a negative ninhydrin test was attained. All peptides were purified by HPLC on a reverse-phase $\mathrm{C} 18$ column.

\section{Internalization of Peptides in Cells}

Peptides were internalized in the cytoplasm of homogenized spleen cells from BALB/c mice by osmotic lysis of pinosomes induced by hypertonic shock as described $(20,24)$ using $300 \mu \mathrm{g} / \mathrm{ml}$ of peptide.

\section{Induction of CTL}

Groups of three 6-week-old female BALB/c mice were primed by ip injection of $100 \mu \mathrm{g}$ of relevant peptide dissolved in $0.5 \mathrm{ml}$ of RPMI 1640 solution at Days 1,8 , and 15. Alternatively, mice were immunized ip with a single dose of syngenic spleen cells $\left(5 \times 10^{6}\right.$ cells in $0.5 \mathrm{ml}$ of RPMI 1640$)$ having been submitted to hypertonic treatment in the presence of peptide. A week after the third injection of peptide or 3 weeks after immunization with cells, the animals were killed and their spleens were removed. Spleen cells were restimulated with $5 \mu \mathrm{g} / \mathrm{ml}$ of the relevant peptide according to Ishioka et al. (12). Cytolytic activity was measured 5 days after initial culture and after establishing CTL lines by repeated restimulations.

\section{Cytotoxicity Assay}

CTL activity was measured using the conventional cytotoxicity assay (12). Target cells P815 (H-2 ${ }^{\mathrm{d}}$-restricted) or EL-4 (H-2 ${ }^{\mathrm{b}}$-restricted) previously incubated with $5 \mu \mathrm{g} /$ 
$\mathrm{ml}$ of relevant peptide were used. The assays were done in triplicate; the spontaneous release was in all cases below $20 \%$ of total release.

\section{Immunization Experiments for Antibody Induction}

BALB/c mice were immunized by ip injection as previously described (6).

\section{Assessment of the Topography of Peptides with Antibodies}

The degree of "surface exposure" of regions from the peptide constructs was assessed by ELISA (6) using specific anti-peptide antibodies for each region. For the competition experiments, the antibodies were incubated with free competitor peptide in solution for $1 \mathrm{hr}$ at $37^{\circ} \mathrm{C}$ before adding this mixture to the ELISA well containing the peptide adsorbed on the plastic.

\section{RESULTS}

To test if constructs of the type $\mathrm{TD}_{\mathrm{c}}-\mathrm{TD}_{\mathrm{h}}$ or $\mathrm{TD}_{\mathrm{h}}-\mathrm{TD}_{\mathrm{c}}$ could induce CTL in vivo we synthesized KQIINMWQEVGKAMYA (from now on KQI) and RIQRGPGRAFVTIGK (RIQ), encompassed respectively by amino acids 428-443 and 315-329 from HIV-1-IIIB gp 20 (positions according to Ratner et al (25)). We also synthesized the constructs RIQRGPGRAFVTIGKKQIINMWQEVGKAMYA (RIQ-KQI) and KQIINMWQEVGKAMYARIQRGPGRAFVTIGK (KQI-RIQ) representing the two possible $\mathrm{N}$-terminal to $\mathrm{C}$-terminal permutations $\left(\mathrm{TD}_{\mathrm{c}}-\mathrm{TD}_{\mathrm{h}}\right.$ or RIQ-KQI and $T_{D_{h}}-T_{c}$ or KQI-RIQ) of the above peptides. KQI and RIQ have been reported as $\mathrm{TD}_{\mathrm{h}}$ and $\mathrm{TD}_{\mathrm{c}}$ in BALB/c mice, respectively $(9,26)$.

\section{Induction of CTL by Immunization with Free Peptides}

To attempt CTL induction in vivo, five groups of BALB/c mice were immunized with peptides RIQ, KQI, RIQ-KQI, KQI-RIQ, and a mixture of KQI and RIQ, respectively. The spleen cells of each group of mice were isolated and cultured in vitro for 5 days under stimulation with different combinations of the above peptides. These cell cultures were next assayed for cytolytic activity against radioactively labeled target cells previously incubated with different peptides.

Figure 1 shows that specific cytolitic activity could be induced by in vivo priming with peptide RIQ-KQI (panels a and b) but not with free RIQ or with KQI-RIQ (panels $d$ and e), respectively. Immunization with a mixture of RIQ and KQI gave lower, but significant levels of CTL. No CTL could be induced with free KQI (data not shown).

A peptide KQI-KK-RIQ, having two potential cleavage sites at the frontier between KQI and RIQ (the two lysines in bold), was synthesized and tested. This peptide was unable to induce CTL in vivo (data not shown), a result that was confirmed in another group of experiments (Table 2).

\section{Mapping the Surface of Peptides with Antibodies}

The degree of "surface exposure" of KQI and RIQ in the above peptide constructs was tested by ELISA with anti-RIQ- and anti-KQI-specific antibodies (induced by immunization with free RIQ and KQI, respectively). Table 1 shows that the KQI 

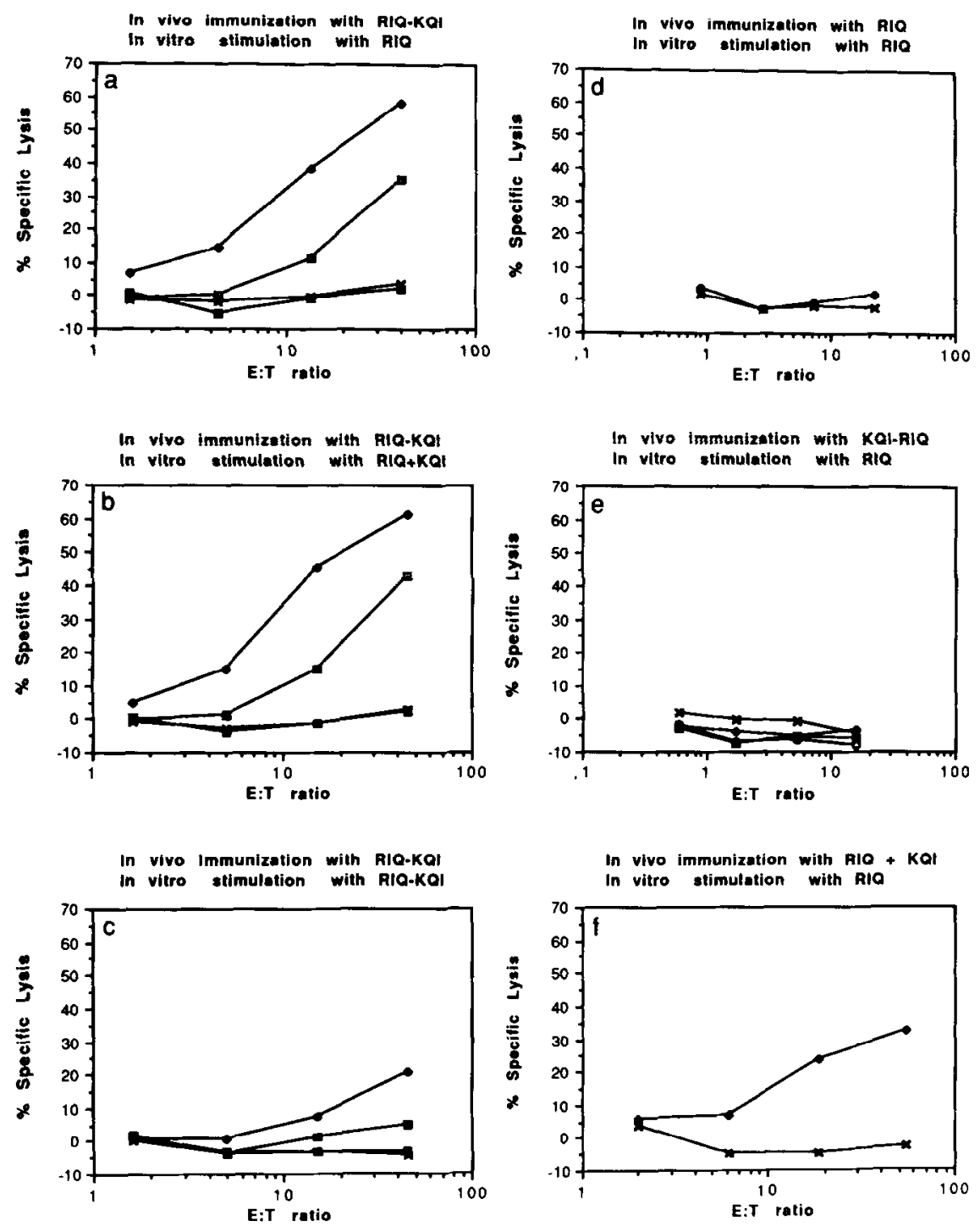

FIG. 1. CTL activity of spleen cells of BALB/c mice after in vivo immunization and in vitro restimulation with the peptides shown on top of each panel. Activity is expressed as the percentage of specific lysis of P815

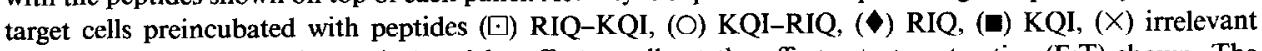
control peptide. This lysis was induced by effector cells at the effector-to-target ratios (E:T) shown. The irrelevant control peptide corresponds to FERFEIFP, which encompasses amino acids $111-118$ of influenza virus hemagglutinin.

moiety is well recognized by anti-KQI antibodies in construct RIQ-KQI but not in KQI-RIQ or KQI-KK-RIQ. By contrast, the RIQ moiety is well recognized by antiRIQ antibodies in KQI-RIQ, KQI-KK-RIQ but not in RIQ-KQI. Qualitatively equivalent results were obtained in inhibition experiments using these pcptide constructs to neutralize the recognition of RIQ and KQI (adsorbed on the ELISA plate) by anti-RIQ and anti-KQI antibodies (data not shown). 
TABLE 1

Recognition Antibody Titers ${ }^{a}\left(\times 10^{-3}\right)$ of RIQ and KQI in Three Different Peptide Constructs by Antisera Specific for Each of These Moieties

\begin{tabular}{lcc} 
Peptide construct & $\begin{array}{c}\text { Recognition by anti-KQI } \\
\text { antibodies }\end{array}$ & $\begin{array}{c}\text { Recognition by anti-RIQ } \\
\text { antibodies }\end{array}$ \\
\hline RIQ-KQI & 10 & 0.9 \\
KQI-RIQ & 0.8 & 13 \\
KQI-KK-RIQ & 2 & 13 \\
\hline
\end{tabular}

${ }^{a}$ The titers shown are the mean from three different mice.

Induction of CTL with Peptide-Containing Cells as Compared to Immunization with Free Peptides

To study the effect of peptide internalization in the cell on CTL induction in vivo, mice were immunized with one of the following peptides: RIQ, RIQ-KQI, KQI-RIQ, KQI-KK-RIQ, and a mixture of KQI and RIQ or with syngenic spleen cells subjected to peptide internalization.

In Table 2 we summarize the results obtained with both types of immunizations. In the group immunized with free peptides, specific cytolitic activity could be induced by in vivo priming with a peptide construct consisting of a colinear combination of a $\mathrm{TD}_{\mathrm{c}}-\mathrm{TD}_{\mathrm{h}}$ (RIQ-KQI) amino acid sequences, and to a lower extent after in vivo priming with a mixture of RIQ and KQI, thus confirming the results of immunization experiments shown in Fig. 1. No induction was achieved by priming with KQI-RIQ (as in Fig. 1) or with KQI-KK-RIQ. By contrast, immunization with spleen cells containing RIQ-KQI, KQI-RIQ, or KQI-KK-RIQ could all induce CTL in vivo whereas immunization with spleen cells containing a mixture of RIQ and KQI gave a marginal response. No response could be induced after immunization with free RIQ or with RIQ-containing cells. No significant response was obtained after in vivo immunization with RPMI alone, or with spleen cells subjected to hypertonic shock in the absence of peptide, and in vitro restimulation with peptides.

\section{TABLE 2}

Percentage of Specific Lysis Induced after Immunization with Free Peptide or with Peptide-Containing Syngenic Cells

\begin{tabular}{lcc}
\hline Peptide tested & $\begin{array}{c}\text { Induced with free } \\
\text { peptide }\end{array}$ & $\begin{array}{c}\text { Induced with peptide- } \\
\text { containing cells }\end{array}$ \\
\hline RIQ-KQI & 31 & 28 \\
KQI-RIQ & 13.5 & 22 \\
KQI + RIQ & 18 & 14 \\
RIQ & 13.2 & 11 \\
KQI-KK-RIQ & 6 & 30 \\
None & 7 & 10 \\
\hline
\end{tabular}

Note. Results were obtained after a single in vitro restimulation with free RIQ and testing CTL activity using P815 cells incubated with RIQ. The effector-to-target ratio was 30:1 in both experiments. 


\section{Surface Phenotype and Class 1 MHC Restriction of Induced CTL}

To characterize the lymphocytes induced after in vivo priming with RIQ-KQI, these lymphocytes were treated with fluorescently labeled anti-CD4 and anti-CD8 antibodies and analyzed by flow cytometry. This showed that around $95 \%$ of them were conventional $\mathrm{CD} 8^{+} \mathrm{CD}^{-}$. Moreover, only P815 target cells $\left(\mathrm{H}-2^{\mathrm{d}}\right.$-restricted) but not EL-4 cells $\left(\mathrm{H}-2^{\mathrm{b}}\right.$-restricted), incubated with RIQ, were lysed by these lymphocytes (data not shown). Since these target cells are $\mathrm{Ia}^{-}$, it can be concluded that the induced $\mathrm{CTL}$ are $\mathrm{H}-2^{\mathrm{d}}$ class I-restricted.

\section{DISCUSSION}

\section{CTL Induction with Peptides, Effect of Epitopes within Constructs}

Figures $1 \mathrm{a}$ and $\mathrm{lb}$ show that specific cytolitic activity can be induced by in vivo priming with a peptide construct consisting of a colinear combination of a $T D_{c}-T_{h}$ (RIQ-KQI) amino acid sequence. This induction cannot be obtained in the absence of KQI, that is, induction of CTL requires help from KQI (compare Fig. 1a with Fig. 1d). The in vitro restimulation does not require KQI since similar percentages of specific lysis can be obtained with and without KQI in the medium (compare Fig. 1a with Fig. 1b). However, as expected, the presence of RIQ during restimulation is essential for cytolitic activity because if only KQI is used no lysis is observed (data not shown).

An interesting aspect of this work is the finding that although CTL priming in vivo is efficiently attained with RIQ-KQI, restimulation in vitro prefers free RIQ over RIQ$\mathrm{KQI}$ (compare Figs. $1 \mathrm{a}$ and $1 \mathrm{~b}$ with $1 \mathrm{c}$ ). Moreover, the relative position of RIQ and $\mathrm{KQI}$ has a dramatic effect on CTL induction in vivo. Thus, RIQ-KQI is active as judged by the percentages of specific lysis induced after in vitro restimulation with either RIQ alone or with a mixture of RIQ and KQI (see Figs. la and lb) whereas KQI-RIQ does not show any sign of activity after in vitro restimulation with RIQ (compare Fig. 1a with Fig. 1e). These results suggested to us that enzymatic processing to free active RIQ might be more favorable in RIQ-KQI than in KQI-RIQ, a similar result to the one found for $\mathrm{TD}_{\mathrm{h}}$-hapten peptide constructs concerning the induction of anti-hapten antibodies (6). It is interesting to note that in the sequence RIQRGPGRAFVTIGKKQIINMWQEVGKAMYA (construct RIQ-KQI) two residues of $\mathrm{K}$ (in bold) are side by side in positions 15 and 16. These residues might define a more accessible trypsin-like cleavage site to generate free RIQ, a situation which would not be as favorable in peptide KQIINMWQEVGKAMYARIQRGPGRAFVTIGK. Thus, active $T D_{c}-T_{h}$ or $T D_{h}-T D_{c}$ peptide constructs might need to have a "cleavable" site between the $T D_{c}$ and $T D_{h}$ sequences. The understanding of how these constructs are processed would greatly facilitate the engineering of tailor-made constructs for a given individual, that is, of how to use $T_{\mathrm{c}}$ and $\mathrm{TD}_{\mathrm{h}}$ sequences recognized by class I and class II MHC molecules of this individual. Irrespective of interpretation, the experimental results discussed above, stress the importance of choosing the most adequate position of both $\mathrm{TD}_{\mathrm{c}}$ and $\mathrm{TD}_{\mathrm{h}}$ to generate active peptide constructs.

Another aspect concerning the induction of CTL in vivo is whether the $\mathrm{TD}_{\mathrm{c}}$ and $\mathrm{TD}_{\mathrm{h}}$ need to be covalently linked to induce CTL, or perhaps it might suffice to prime with a mixture of them, a result that might resemble the induction of antibodies using 
another type of peptide constructs (7). Comparison of Figs. 1a and 1b with Fig. If show that CTL induction is clearly more efficient after priming with RIQ-KQI than after priming with a mixture of RIQ and KQI. In this last case, lower but significant CTL induction seems to have taken place.

Since efficient processing of the constructs inside the cell, to liberate the $\mathrm{TD}_{\mathrm{c}}$ (RIQ in the above constructs), might be important for the induction of CTL, we synthesized the peptide KQI-KK-RIQ, having two added potentially cleavable sites at the frontier between KQI and RIQ (the two lysines in bold) to attempt to improve processing. However, this peptide was unable to induce CTL in vivo. This result made us think that the lack of activity of KQI-KK-RIQ and of KQI-RIQ might perhaps be related to poor internalization of these constructs rather than to inefficient processing.

\section{Surface Exposure of Epitopes}

Since internalization of peptides inside the cells might be related to the topography of peptides, we thought of mapping the surface of our constructs with anti-RIQ and anti-KQI antibodies. Table 1 shows that the KQI moiety is well "surface exposed" only in RIQ-KQI, which is the sole active peptide construct. Since the KQI moiety but not RIQ is surface exposed in RIQ-KQI, it would seem logical that if internalization of RIQ-KQI inside the cell takes place, this should happen via KQI.

\section{Effect of Peptide Internalization on CTL Induction}

To study the effect of peptide internalization in the cell on CTL induction in vivo, we "forced" internalization of our constructs by hypertonic shock $(20,24)$. The cells thus obtained were used for immunization experiments. Table 2 shows that by contrast with immunization with frec peptides, where only RIQ-KQI is active, immunization with peptide-containing cells (RIQ-KQI, KQI-RIQ, and KQI-KK-RIQ) are all active. This proves that peptide internalization render KQI-RIQ, and KQI-KK-RIQ active. It is interesting to note that KQI-KK-RIQ is as active as RIQ-KQI but more active than KQI-RIQ, this might be related to improved processing due to the added lysines. Moreover, because CTL activity was not induced by RIQ alone in either of the two groups of immunized mice, it would seem likely that in addition to a potential role of KQI in the internalization of RIQ-KQI, help from KQI might be required for CTL induction. However, KQI seems to be more effective when covalently linked to RIQ. These observations are in agreement with the results reported by Schild for a lipopeptide, where the lipophilic moiety seems to play a role in the internalization (14) and has $\mathrm{TD}_{\mathrm{h}}$ character in another type of construct (18). For similar reasons, it would seem that shorter peptides (15-17) able to induce CTL in vivo might contain both properties (internalization ability and $\mathrm{TD}_{\mathrm{h}}$ character) as the lipophilic moiety or the $\mathrm{KQI}$ of the above constructs.

We believe that our results have important implications in vaccination and in the treatment of chronic infections, i.e., AIDS and hepatitis B and C. Thus, if the major $\mathrm{TD}_{\mathrm{c}}$ and $\mathrm{TD}_{\mathrm{h}}$ determinants (of the corresponding viral antigens) recognized by class I and class II MHC molecules of most individuals were known (a research field which is quickly developing) constructs like the ones described above could be engineered to protect against natural infection and to treat chronically infected individuals. 


\section{ACKNOWLEDGMENTS}

We thank the Gobierno Foral de Navarra, the Fundación Ramón Areces, and the Comisión Interministerial de Ciencia y Tecnología (C.I.C.Y.T) for financial support. We also thank Drs. G. Sterkers, D. Zeliszewski, and B. Cullmann for the gift of P815 and EL-4 cells and for their advice on the cytotoxicity protocols.

\section{REFERENCES}

1. Good, M. F., Malloy, W. L., Lunde, M. N., Margalit, H., Cornette, J. L., Smith, G. L., Moss, B., Miller, L. H., and Berzofsky, J. A., Science 235, 1059, 1987.

2. Leclerck, C., Przewlocki, G., Chutze, M. P., and Chedid, L., Eur. J. Immunol. 17, 269, 1987.

3. Borrás-Cuesta, F., Petit-Camurdan, A., and Fedon, Y., Eur. J. Immunol. 17, 1213, 1987.

4. Borrás-Cuesta, F., Fedon, Y., and Petit-Camurdan, A., Eur. J. Immunol. 18, 199, 1988.

5. Cox, J. H., Ivanyi, J., Young, D. B., Lamb, J. R., Syred, A. D., and Francis, M. J., Eur. J. Immunol. 18, 2015, 1988.

6. Golvano, J. J., Lasarte, J. J., Sarobe, P., Gullón, A., Prieto, J., and Borrás-Cuesta, F., Eur. J. Immunol. 20, 2363, 1990.

7. Sarobe, P., Lasarte, J. J., Golvano, J., Gullón, A., Civeira, M. P., Prieto, J., and Borrás-Cuesta, F., Eur. J. Immunol. 21, 1555, 1991.

8. Orentas, R. J., Hildreth, J. E. K., Obath, E., Polydefkis, M., Smith, G. E., Clements, M. L., and Siliciano, R. F., Science 248, 1234, 1990.

9. Takahashi, H., Cohen, J., Hosmalin, A., Cease, K. B., Houghten, R., Cornette, J. L., DeLisi, C., Moss, B., Germain, R. N., and Berzofsky, J. A., Proc. Natl. Acad. Sci. UISA 85, 3105, 1988.

10. Takahashi, H., Takeshita, T., Morein, B., Putney, S., Germain, R. N., and Berzofsky, J. A., Nature (London) 344, 873, 1990.

11. Carbone, F., and Bevan, M. J., J. Exp. Med. 169, 603, 1989.

12. Ishioka, G. Y., Colon, S., Miles, C., Grey, H. M., and Chesnut, R. W., J. Immunol. 143, 1094, 1989.

13. Deres, K., Schild, H., Wiesmüller, K.-H., Jung, G., and Rammensee, H.-G., Nature (London) 342, 561, 1989.

14. Schild, H., Deres, K., Wiesmüller, K.-H., Jung, G., and Rammensee, H.-G., Eur. J. Immunol. 21, 2649, 1991.

15. Aichele, P., Hengartner, H., Zinkernagel, R. M., and Schulz, M., J. Exp. Med. 171, 1815, 1990.

16. Schulz, M., Zinkernagel, R. F., and Hengartner, H., Proc. Nat. Acad. Sci. USA 88, 991, 1991.

17. Kast, W. M., Roux, L., Curren, J., Blom, H. J. J., Voordow, A. C., Meloen, R. H., Kolakofsky, D., and Melief, C. J. M., Proc. Nat. Acad. Sci. USA 88, 2283, 1991.

18. Jung, G., Wiesmüller, K.-II., Becker, G., Buhring, II.-J., and Bessler, W. G., Angew. Chem. 24, 872, 1985.

19. Sette, A., Buus, S., Appella, E., Smith, J. A., Chesnut, R., Milles, G., Colon, S. M., Grey, H. M., Proc. Natl. Acad. Sci. USA 86, 3296, 1989.

20. Moore, W. M., Carbone, R. F., and Bevan, J. M., Cell 54, 777, 1988.

21. Merrifield, R. B., J. Am. Chem. Soc. 85, 2149, 1963.

22. Atherton, E., Logan, J. C., and Sheppard, C. R., J. Chem. Soc., Perkin. Trans. 1, 538, 1981.

23. Kaiser, E., Colescott, R. L., Bossinger, C. D., and Cook, P. I., Anal. Biochem. 34, 595, 1970.

24. Okada, Y. C., and Rechsteiner, M., Cell 29, 33, 1982.

25. Ratner, L., Haseltine, W., Patarca, R., Livak, K. J., Starcih, B., Josephs, S. F., Doran, E. R., Rafalski, J. A., Whitehorn, E. A., Baumeister, K., Ivanoff, L., Petteway Jr., S. R., Pearson, M. L., Lautenberger, J. A., Papas, T. J., Ghtayeb, J., Chang, N. T., Gallo, R. C., and Wong-Staal, F., Nature (London) 313, 277, 1985.

26. Cease, K., Margalit, H., Cornette, J., Putney, S., Robey, W., Ouyang, C., Streicher, H., Fischinger, P., Gallo, R., DeLisi, C., and Berzofsky, J. A., Proc. Natl. Acad. Sci. USA 84, 4249, 1987. 